\title{
Plagiarism in Medical Research: Knowns and Unknowns
}

\author{
S Vijay Shankar ${ }^{1}, K_{\text {Amita }}^{2}$
}

\begin{abstract}
Academic integrity and ethics are an integral part of the good scientific research. Publications in a peer reviewed journal are an important measure of performance in medical institutions. However, today, similar to all other aspects of human life, even research in medicine has seen a tremendous upsurge in various forms of dishonesty, one among it being plagiarism. This article aims focuses on the concepts of plagiarism in medical research. The objectives of this paper are therefore to define plagiarism, to learn the extent of the problem, to discuss various forms of plagiarism; methods to detect and prevent it. A brief insight into the management of the same is given.

KEY WORDS: Management, Plagiarism, Prevention, Research.
\end{abstract}

\section{INTRODUCTION}

Medicine is an ever-changing, vast and expanding subject. The scientific arena is replete with enormous literature available in the form of books, journals, and the web. These data are based on the research which had been conducted at various levels. There are several measures which determine the quality of these researches, foremost being the use of the scientific methodology for conducting and in reporting of the research. With mounting force from the apex bodies and the corresponding institutions, the academicians are under immense stress to perform in the form of publications in peer reviewed journals.

A quality research done and published in a peer reviewed journal becomes a source of information for other researchers, as well as clinicians. In this era of evidence-based medicine, to impart best care for the patients, it is mandatory for the research work published to have certain values of truth, trust, honesty, and responsibility. ${ }^{[1]}$ For a researcher to

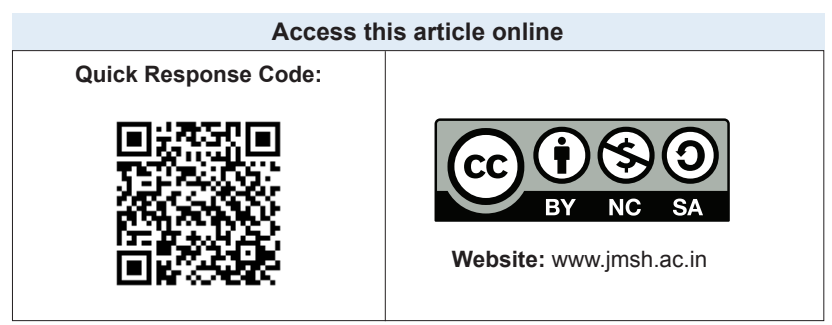

uphold high-quality standards, these values should be applied at all levels of the research process, beginning from planning of the study, methodology, data collection, observations, analysis, discussion and conclusion including the tables and figures used. ${ }^{[2]}$ It is must to follow the principles of good clinical practice and good scientific practice. ${ }^{[3,4]}$ This is especially so because finally in the field of medicine the health of a common man is at stake. However, an area of concern in research is scientific misconduct. One of the major type of this unacceptable behavior is Plagiarism. This article is intended to provide a brief insight regarding the various aspects of plagiarism.

\section{DEFINITION}

The word plagiarism is derived from Latin word, "plagiarius" - an abductor and "plagiare" - to steal. Dictionary meaning of plagiarism is "to steal and pass off as one's own (the ideas or words of another) without crediting the source."[5] Though several definition exists; an attempt has been made to provide standard and consensus definition of this term.

World Association of Medical Editors (WAME) define plagiarism as; "The use of others published and unpublished ideas or words and or other intellectual property without attribution or permission, and presenting them as new and original rather than derived from an existing source.”[6]

${ }^{1}$ Professor, Department of Pathology, Adichunchanagiri Institute of Medical Sciences, Balagangadharanatha Nagara, Mandya, Karnataka, India, ${ }^{2}$ Associate Professor, Department of Pathology, Adichunchanagiri Institute of Medical sciences, Balagangadharanatha Nagara, Mandya, Karnataka, India Address for correspondence:

Dr. S Vijay Shankar, Department of Pathology, Adichunchanagiri Institute of Medical Sciences, Balagangadharanatha Nagara, Nagamangala Taluk, Mandya - 571 448, Karnataka, India. Phone: +91-9845357933. E-mail: vijayshankarpatho@gmail.com 
Committee on Publication Ethics (COPE): The COPE defines plagiarism as follows: "Plagiarism ranges from the unreferenced use of others' published and unpublished ideas, including research grant applicaions, to submission under "new" authorship of a complete paper, sometimes in a different language. It applies to print and electronic versions.' To simplify it WAME states that plagiarism implies when 6 or more consecutive words are copied, in a continuous set of 30 words. $^{[7]}$ However, the seriousness of the crime depends on the extent of the text plagiarized.

\section{IMPACT AND EXTENT OF THE PROBLEM}

Plagiarism has a detrimental effect on the research community, research subjects, and the general public. It brings disreputation to the journal, the institution, and the researcher. It leads to waste of time and resources. Research of such kind can misguide the health care provider, who relies on evidence-based medicine. It is even misleading for the future researchers and funding agencies.

\section{Extent}

Plagiarism in medicine is known since medieval times. To name a few (i) In late 1970, John Darsee, working as a junior scientist in cardiology was confirmed to have fabricated electrocardiogram data and publishing 100 faked articles for over one and a half decade. Eric Poehlman, a physiologist, fabricated and falsified data in academic articles and in funding proposals between 1992 and 2002, at the University of Vermont in Burlington. He was imprisoned and banned from obtaining funds. Andrew Wakefield, in 1998, published wrong data on the relation of MMR vaccine to autism. This led to a decrease in vaccination rates which further resulted in an increase in the disease incidence. ${ }^{[8]}$ The Croatian Medical Journal recorded 11\% plagiarism over duration of 2 years. ${ }^{[9]}$ Soo Young accidentally detected a few cases of plagiarism which finds mention in the editorial of the Korean Journal of Forensic Medicine. ${ }^{[10]}$

As is aptly quoted by T S Eliot, "Immature poets imitate. Mature poets steal;" plagiarism has its roots buried in education, among the student fraternity. Students being immature in the field of research, are not well versed with ethics, tend to indulge in plagiarism by replicating their dissertation, seminars, and other assignments. About $56 \%$ of medical students in America and 90\% in Croatia plagiarized their work. ${ }^{[11,12]}$ Many cases of plagiarism have been found and subsequently reported in Europe, Iran, and Australia. ${ }^{[7]}$ The cases are on rife in India too. However, very few journals have published data related to plagiarism detection rates and subsequent action taken against the authors.

The exact prevalence of plagiarism is difficult to determine due to the meager fact that most of it goes undetected. Ignorance, lack of education, publish, or perish ideology gaining momentum in medical schools and colleges, has lead to an alarming increase in plagiarism. The advancement in information technology has compounded the problem.

\section{TYPES OF PLAGIARISM}

The broad categories of plagiarism are: Plagiarism of ideas and plagiarism of text. The latter is known as verbatim Plagiarism. Different types of plagiarism exist of which few deserve to be mentioned here. Intentional plagiarism refers to using others work without attribution. Such an act has the intention of deceit and is considered as a serious form of misconduct. Unintentional plagiarism occurs without an author's knowledge due to wrong paraphrasing or improper citation. Mosiac plagiarism occurs when one copies exact statements as that from the original source and does not cite it. Self-plagiarism is the use of a part of one's own previously published work without mentioning the original source. ${ }^{[13]}$

The plagiarism of ideas is worse than plagiarism of text. Some argue that plagiarism of text in scientific articles may not prove such a grave sin as eloquence is not inborn in everyone and words and sentences to express an idea may yet be permissible. This may prove a greater offense in the field of art and language where emphasis is giving more to expression. In the scientific world, the focus is on hard fact, which promote evidence-based medicine.

Borrowing of original ideas and calling them one's own is a greater breach of confidence and only one's own integrity and honesty may control this.

Why do we plagiarize - Whether ideas or text?

Some of the reasons to this could be - Lack of originality; lack of an inquisitive mind and lack of confidence in the expression of innovation and possibly lack of adequate knowledge. Verbatim plagiarism may be a result of easy accessibility to 
text on net, laziness to express and a desire to lengthy expression. Both types should be condemned.

\section{DETECTION AND INTERPRETATION}

To address the issue of verbatim plagiarism, several software has been developed in the past three decades. Some of them are available for free whilst some are paid. The articles to be checked have to be uploaded as a word or Portable Document Format on the site. The software then scans and compares the text with the literature available in various databases. The results are expressed in the form of percentages.

Croatian Medical Journal considers plagiarism if more than $10 \%$ text similarity is noted, while others consider $25 \%$ or $30 \%$. How much of plagiarism is acceptable is determined by the editors of the journal. Further manual verification is mandatory, the guidelines for which are available on COPE website. ${ }^{[11]}$ Plagiarism in the results and discussion part of the work is not tolerated. However, minor amount in methodology can be accepted with proper citation and paraphrasing. ${ }^{[11]}$

Much is spoken about verbatim plagiarism, despite the fact that plagiarism of ideas is a more serious misdemeanor, which is difficult to detect. Plagiarism of ideas can be detected by selecting reviewers' expertise in that particular topic and subject.

\section{PREVENTION AND MANAGEMENT}

COPE has provided guidelines for dealing with scientific misconduct including plagiarism. If the manuscript is a pure copy and paste material, then editors have the right to reject it uprightly. In such cases, the editors must inform and seek response from the head of the department and the institution in which the research was conducted. In the wake of plagiarized content being received from eminent researchers and reputed institutions, such authors should be blacklisted, and their work in future should be scrutinized with extra effort. If the manuscript is worth publishing, in terms of new ideas but with a major amount of plagiarism, the author is encouraged to rewrite and resubmit. ${ }^{[4]}$ In the case of joint publications as in manuscripts with multiple authors, all the authors are held responsible for the misconduct. ${ }^{[14]}$

\section{PREVENTING PLAGIARISM}

Verbatim plagiarism is copy and paste, if we train ourselves in comprehension and understand the article and rewrite the salient features in our own language, this would indeed take care of it.

Before starting a research work, conduct a detailed study of the past and the existing facts.

1. Follow proper scientific methodology while conducting the research

2. During writing, use your own words. Paraphrase wherever necessary. That means to use own words for information taken from other sources

3. Provide proper citation for ideas and text taken from another sources

4. Sources used should be reliable

5. When some statements are copied word to word, put them in quotations

6. If ideas or text are borrowed from one's own previous published work, it needs to be cited; else it amounts to self-plagiarism

7. Mention the references with complete bibliographic information

8. Last but not the least, be honest with yourself. ${ }^{[14,15]}$

\section{LIMITATIONS}

There are certain limitations which need attention.

Despite inflation of plagiarism in scientific publications, there is no consensus on how much amounts to plagiarism. Several software's are available for detecting plagiarism, which function differently. Computer software cannot detect plagiarism of ideas and to some extent in figures. ${ }^{[16]}$ The practice of resubmission of the retracted article, due to plagiarism, in some other journal is rampant.

All these issues need to be addressed, which demands establishment in our country of a regional and institutional body which can set up guidelines in these regards. Each institution should have a research integrity body which keeps an eye on all the research conducted by the faculty and students and persuades them to maintain high-quality standards and ethics in scientific research. Regular training for educating students and faculty, in the form of seminars and workshops should be conducted in the Institution on Research Integrity and Ethics.

Editors of the journals also have the impetus of avoiding scientific misconduct in the form of plagiarism by adopting and displaying the policy statement on plagiarism and by publishing the plagiarized data in the editorials on a regular basis. 


\section{CONCLUSION}

"No legacy is so rich as honesty." Quotes William Shakespeare.

Plagiarism is a form of scientific misconduct which demands a zero tolerance attitude. It creates an environment of falsehood and dishonesty among the colleagues. Institutions should maintain certain standards in conducting research and publication by establishing a cell on research integrity to govern, guide and educate the students and faculty on research integrity on a regular basis, as well as establish stringent rules to curb plagiarism and any form of scientific misconduct.

\section{ACKNOWLEDGEMENTS}

We would like to thank Dr. M G Shivaramu, Principal Adichunchanagiri Institute of Medical sciences, Balagangadharanatha Nagara, Nagamangala Taluk, Mandya District \& Executive editor in chief, JMSH for encouraging us to write this manuscript. We thank Dr. Shameem Sharieff Professor and HOD, Department of Pathology, MVJMC \& RH, Hosakote, Bangalore for providing valuable comments and suggestions that greatly improved the manuscript.

\section{REFERENCES}

1. Gasparyan AY, Ayvazyan L, Kitas GD. Biomedical journal editing: Elements of success. Croat Med J 2011;52:423-8.

2. Masic I. Plagiarism in scientific research and publications and how to prevent it. Mater Sociomed 2014;26:141-6.

3. International Committee of Medical Journals Editors. Recommendations for the Conduct, Reporting, Editing, and Publication of Scholarly Work in Medical Journals. Available from: http://www.icmje.org/recommendations/. [Last accessed on 2015 Dec 05].

4. Committee on Publication Ethics. COPE. Code of Conduct and Best Practice Guidelines for Journal editors. Available from: http://www.publicationethics.org/resources/code-conduct.
[Last accessed on 2015 Oct 05].

5. Oxford Dictionary. Available from: http://www. oxforddictionaries.com/definition/english/plagiarism. [Last accessed on 2015 Jun 10].

6. WAME Publication Ethics Policies for Medical Journals. Available form: http://www.wame.org/resources/ethicsresources/publication-ethics-policies-for-medical-journals/. [Last accessed 2015 Oct 05].

7. Masic I. Plagiarism in scientific publishing. Acta Inform Med 2012;20:208-13.

8. Anderson MS, Shaw MA, Steneck NH, Konkle E, Kamata T. Research integrity and misconduct in the academic profession. In: Paulen MB, editor. Higher Education: Handbook of Theory and Research. Munich, Germany: Springer; 2013. p. 217-61.

9. Marusic A. Importance of Ethical Publishing in Developing Countries. Acta Inform Med 2012;20:4.

10. Kim SY. Plagiarism detection. Korean J Fam Med 2013;34:371.

11. Baždaric K, Bilic-Zulle L, Brumini G, Petrovecki M. Prevalence of plagiarism in recent submissions to the Croatian medical journal. Sci Eng Ethics 2012;18:223-39.

12. Bilic-Zulle L, Frkovic V, Turk T, Azman J, Petrovecki M. Prevalence of plagiarism among medical students. Croat Med J 2005;46:126-31.

13. Kumar PM, Priya NS, Musalaiah S, Nagasree M. Knowing and avoiding plagiarism during scientific writing. Ann Med Health Sci Res 2014;4:S193-8.

14. Ali J. Plagiarism: An editor's concern. Int J Pharm Investig 2011;1:129-30.

15. Masic I. The importance of proper citation of references in biomedical articles. Acta Inform Med 2013;21:148-55.

16. Wiwanitkit S. Plagiarism and journal editing. Acta Inform Med 2013;21:71.

Financial Support: None; Conflict of Interest: None

How to cite this article: Shankar SV, Amita K. Plagiarism in medical research: Knowns and unknowns. J Med Sci Health 2015;1(3):1-4.

Date of submission: 04-10-2015

Date of peer review: 05-10-2015

Date of acceptance: 05-10-2015

Date of publishing: 10-10-2015 